\title{
Prevalence and determinants of SHS exposure in public and private areas after the 2010 smoke-free legislation in Greece
}

\section{Citation}

Schoretsaniti, Sotiria, Filippos T Filippidis, Constantine I Vardavas, Chara Tzavara, Christine Dimitrakaki, Panagiotis Behrakis, Gregory N Connolly, and Yannis Tountas. 2014. "Prevalence and determinants of SHS exposure in public and private areas after the 2010 smoke-free legislation in Greece." Tobacco Induced Diseases 12 (Suppl 1): A16. doi:10.1186/1617-9625-12S1-A16. http://dx.doi.org/10.1186/1617-9625-12-S1-A16.

\section{Published Version}

doi:10.1186/1617-9625-12-S1-A16

\section{Permanent link}

http://nrs.harvard.edu/urn-3:HUL.InstRepos:12717428

\section{Terms of Use}

This article was downloaded from Harvard University's DASH repository, and is made available under the terms and conditions applicable to Other Posted Material, as set forth at http:// nrs.harvard.edu/urn-3:HUL.InstRepos:dash.current.terms-of-use\#LAA

\section{Share Your Story}

The Harvard community has made this article openly available.

Please share how this access benefits you. Submit a story.

Accessibility 


\title{
Prevalence and determinants of SHS exposure in public and private areas after the 2010 smoke- free legislation in Greece
}

\author{
Sotiria Schoretsaniti ${ }^{*}$, Filippos T Filippidis ${ }^{1}$, Constantine I Vardavas ${ }^{2,3,4}$, Chara Tzavara ${ }^{1}$, Christine Dimitrakaki ${ }^{1}$, \\ Panagiotis Behrakis $3,4,5$, Gregory N Connolly ${ }^{2}$, Yannis Tountas ${ }^{1}$
}

From 11th Annual Conference of the International Society for the Prevention of Tobacco Induced Diseases (ISPTID)

Athens, Greece. 9-11 December 2013

\section{Background}

The objective of the present survey was to assess the extent and socioeconomic determinants of population exposure to secondhand smoke (SHS) in Greece in 2011.

\section{Materials and methods}

The national household survey Hellas Health IV was conducted in October 2011. SHS exposure was based on selfreported exposure within home, workplace and public places.

\section{Results}

$33.1 \%$ of the respondents reported living in a smoke-free home. Smokers $(\mathrm{p}<0.001)$ and single individuals $(\mathrm{p}<0.017)$ were less likely to prohibit smoking at home. SHS exposure at work, in restaurants and in bars/clubs/ cafes was frequently mentioned by $41.6 \%, 84.2 \%$ and $90.5 \%$ respectively. SHS exposure in a bar/club/café was noted more among single individuals $(\mathrm{p}=0.004)$ and those aged $18-34$ years $(\mathrm{p}=0.007)$.

\section{Conclusions}

Inhabitants of rural areas were more likely to report someone smoking indoors in all the above venues. Public health education and effective enforcement of the nationwide smoke-free legislation are imperative.

\footnotetext{
* Correspondence: sschoretsaniti@ispm.gr

${ }^{1}$ Center for Health Services Research, Department of Hygiene, Epidemiology and Medical Statistics,School of Medicine, National and Kapodistrian University of Athens, Athens, 11527, Greece

Full list of author information is available at the end of the article
}

\section{Authors' details}

${ }^{1}$ Center for Health Services Research, Department of Hygiene, Epidemiology and Medical Statistics,School of Medicine, National and Kapodistrian University of Athens, Athens, 11527, Greece. ${ }^{2}$ Center for Global Tobacco Control, Department of Social and Behavioral Sciences, Harvard School of Public Health, West Boston, 02115, Massachusetts, USA. ${ }^{3}$ Smoking and Lung Cancer Research Center, Hellenic Cancer Society, Athens, 11521, Greece. ${ }^{4}$ Foundation for Biomedical Research of the Academy of Athens, Athens, 115 27, Greece. ${ }^{5}$ Department of Environmental Health, Harvard School of Public Health, 677 Huntington Avenue Landmark, West Boston, MA 02115, USA.

Published: 6 June 2014

doi:10.1186/1617-9625-12-S1-A16

Cite this article as: Schoretsaniti et al:: Prevalence and determinants of SHS exposure in public and private areas after the 2010 smoke-free legislation in Greece. Tobacco Induced Diseases 2014 12(Suppl 1):A16.
Submit your next manuscript to BioMed Central and take full advantage of:

- Convenient online submission

- Thorough peer review

- No space constraints or color figure charges

- Immediate publication on acceptance

- Inclusion in PubMed, CAS, Scopus and Google Scholar

- Research which is freely available for redistribution

Submit your manuscript at www.biomedcentral.com/submit
C Biomed Central 